\section{Determination of vitreous interleukin-1 (IL-1) and tumour necrosis factor (TNF) levels in proliferative diabetic retinopathy}

N Demircan', BG Safran², M Soylu', AA Ozcan' and S Sizmaz'
${ }^{1}$ Department of Ophthalmology, Çukurova University, Faculty of Medicine, Adana-Turkey, Balcali, Turkey

\section{${ }^{2}$ Department of} Ophthalmology Numune Hospital, Adana-Turkey, Balcali, Turkey

Correspondence: AA Ozcan Çukurova University Faculty of Medicine, Department of Ophthalmology, Balcali, 01330-Adana, Turkey Tel/Fax: + 903223386442 E-mail: altanoz@cu.edu.tr

Received: 17 May 2005 Accepted in revised form: 31 August 2005

Published online:

11 November 2005

\begin{abstract}
We measured interleukin-1 beta (IL-1 $\beta$ ) and tumour necrosis factor-alpha (TNF- $\alpha$ ) in the vitreous humour and serum of patients with proliferative diabetic retinopathy (PDR), in order to determine the role of these cytokines in the pathogenesis of the disease. Vitreous and serum samples were collected from 21 patients with PDR who were undergoing pars plana vitrectomy. Control vitreous samples were obtained from cadavers and control serum samples from healthy subjects. The cytokines were measured by enzymelinked immunosorbent assay. Vitreous IL-1 $\beta$ and TNF- $\alpha$ concentrations in patients with PDR exceeded those of controls $(P<0.05)$, as did serum IL-1 $\beta$ and TNF- $\alpha$. We suggest that increased vitreous IL-1 $\beta$ and TNF- $\alpha$ levels may play a significant role in the pathogenesis of PDR, which features abnormal cell proliferation and neovascularisation. Eye (2006) 20, 1366-1369. doi:10.1038/sj.eye.6702138; published online 11 November 2005
\end{abstract}

Keywords: proliferative diabetic retinopathy; interleukin-1 beta; tumour necrosis factor-alpha; cytokines

\section{Introduction}

Diabetic retinopathy is one of the most serious complication of diabetes mellitus.

Neovascularisation is the common final pathway in proliferative diabetic retinopathy (PDR) and often leads to vision loss with vitreous haemorrhage, tractional retinal detachment, and neovascular glaucoma.
Vascular, metabolic, endocrine, haematologic, and immunological mechanisms are important in the development of neovascularisation secondary to ischaemia by upregulating the production of growth factors. ${ }^{1-7}$ Interleukins play an important role in the regulation of immune mechanisms, and are also thought to be responsible for the development of PDR. Cytokines such as tumour necrosis factor-alpha (TNF- $\alpha$ ), interleukin-1 beta (IL-1 $\beta)$, and interferon-gama regulate cells and have immune and inflammatory properties. ${ }^{8-10}$ When stimulated by human recombinant IL- $1 \beta$ and TNF- $\alpha$, human RPE cells synthesise and secrete IL-6 and IL- 8 , the former being a potent mediator of inflammation. ${ }^{11}$ In order to determine the relationship between immune mechanisms and diabetic retinopaty, we measured vitreous and serum IL- $1 \beta$ and TNF- $\alpha$ concentrations in patients with PDR.

\section{Materials and methods}

The study group consisted of 21 patients (11 female and 10 male) with the diagnosis of vitreoretinal pathology due to advanced PDR, undergoing pars plana vitrectomy. Their ages ranged from 42 to 70 years (median 61).

Prior to vitrectomy, $0.5 \mathrm{ml}$ vitreous and $5 \mathrm{cc}$ blood samples were obtained from each patient. Vitreous samples $(0.5 \mathrm{ml})$ obtained from eyes of 21 cadavers with ageing match, within $2 \mathrm{~h}$ of death, were used as controls. No specimens were taken from cases with ocular pathology, sepsis, neuroviral pathology, hepatitis A, B, C, or malignancy. Serum was taken from a control group consisting of 21 
healthy individuals with ageing match. Serum and vitreous samples were collected in sterile Ependorf tubes and stored at $-70^{\circ} \mathrm{C}$ until the time of assay. We used an enzyme-linked immunosorbent assay (ELISA) kit (Immunotech, catalog no.10755) for IL-1 $\beta$ measurements. TNF- $\alpha$ was quantified with an ELISA kit (The Biosurce International Cytoscreen, catalog no.Dta 50-RD systems). The values were read at $450 \mathrm{~nm}$ in an ELISA reader and IL- $1 \beta$ and TNF- $\alpha$ concentrations were calculated from specific calibration curves prepared with known standard solutions.

\section{Statistical analysis}

Since vitreous IL- $1 \beta$, serum IL- $1 \beta$, vitreous TNF- $\alpha$ and serum TNF- $\alpha$ concentrations were non-normally distributed, the Mann-Whitney U-test and Spearman's Rank Correlation test were used in the analysis. $P$-values less than 0.05 were considered significant. Immunological parameters were described by mean, standard deviation (SD), median (M), and range (R).

\section{Results}

In PDR patients, the mean levels of vitreous and serum IL- $1 \beta$ were $34.1 \pm 84.3$ and $12.8 \pm 21.7 \mathrm{pg} / \mathrm{ml}$; whereas the TNF- $\alpha$ were $160.7 \pm 218.9$ and $103.8 \pm 199.9 \mathrm{pg} / \mathrm{ml}$, respectively. In controls, the mean levels of vitreous and serum IL- $1 \beta$ were $5.5 \pm 5.8$ and $0.41 \pm 1.91 \mathrm{pg} / \mathrm{ml}$; whereas the TNF- $\alpha$ were $12.3 \pm 6.19$ and $5.9 \pm 4.5 \mathrm{pg} / \mathrm{ml}$, respectively. Both vitreous and serum IL- $1 \beta$ and TNF- $\alpha$ levels were significantly greater in the PDR patients than the controls $(P<0.0001)$. Vitreous and serum IL- $1 \beta$ and TNF- $\alpha$ concentrations of both groups are shown in Tables 1 and 2.

\section{Discussion}

Immunological, biochemical, and genetic factors are thought to contribute to the pathogenesis of intraocular changes in PDR. Several studies have addressed the recent hypothesis that the reduced angiogenesis of PDR is due to the release of growth factors and interleukins from the ischaemic retina. ${ }^{12-16}$ Abnormal production of

Table 1 The levels of IL-1 $\beta$ and TNF- $\alpha$ in patients with PDR and controls

\begin{tabular}{lcrr}
\hline Cytokines & $\begin{array}{c}\text { PDR }(\mathrm{n}=21) \\
\text { Mean } \pm S D(\text { median }(\text { min-max }))\end{array}$ & $\begin{array}{c}\text { Control }(\mathrm{n}=21) \\
\text { Mean } \pm S D(\text { median }(\text { min-max }))\end{array}$ & P-value \\
\hline IL-1 $\beta$ _Serum & $12.8 \pm 21.7(7.6(2.6-107.0))$ & $0.41 \pm 1.91(0(0-8.7))$ & 0.0001 \\
IL-1 $\beta$-Vitreous & $34.1 \pm 84.3(9.5(6.3-388.9))$ & $5.5 \pm 5.8(5.4(0-25.0))$ & 0.0001 \\
TNF- $\alpha$ _Serum & $103.8 \pm 199.9(19.2(2.51-906.2))$ & $5.9 \pm 4.5(6.5(0-13.1))$ & 0.0001 \\
TNF- $\alpha$-Vitreous & $160.7 \pm 218.9(77.1(7.4-988.2))$ & $12.3 \pm 6.19(12.1(0-23))$ & 0.0001 \\
\hline
\end{tabular}

Table 2 Boxplot diagram of IL- $1 \beta$ and TNF- $\alpha$ levels in patients with PDR and controls
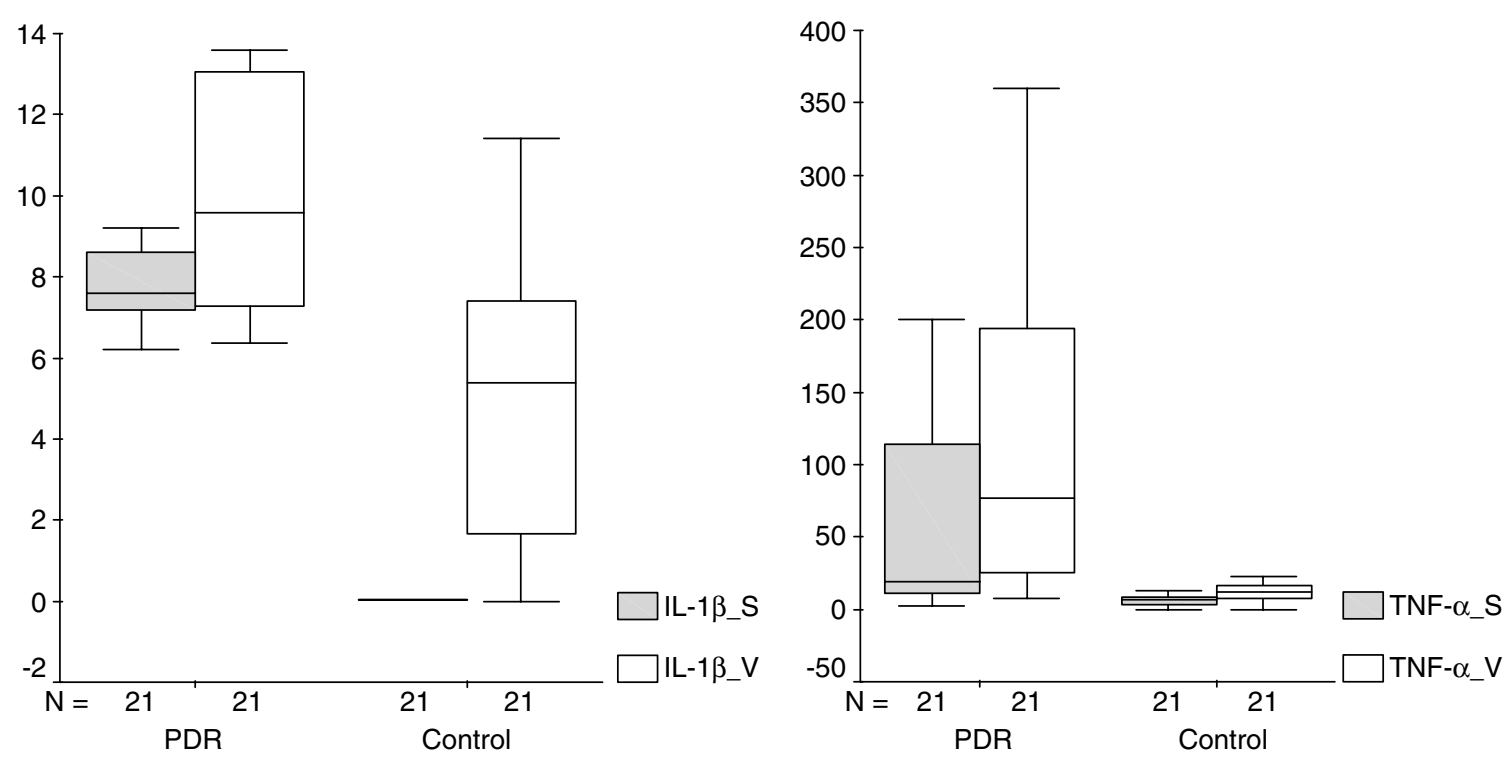
cytokines such as IL- $1 \beta$, TNF- $\alpha$, IL-6, IL- 8 may also be important. ${ }^{17-20}$ The biological effects of IL- $1 \beta$ depend on the target cell. Together with TNF- $\alpha, \mathrm{IL}-1 \beta$ is responsible for angiogenic activity. It stimulates not only collagen synthesis, but also glial cells and fibroblasts, resulting in proliferation and contraction.

Experimental studies have demonstrated the in vivo angiogenic activity of IL- $1 \beta$, and its influence on the development of ocular neovascularisation, especially in the cornea and iris. ${ }^{15,21}$ Studies of vitreous and serum IL-1 $\beta$ concentrations in patients with proliferative vitreoretinopathy (PVR) and PDR have come to different conclusions. ${ }^{14,22,23}$ Kaufmann et $a l^{23}$ showed an increased vitreous IL-6 in $29 \%$ of patients with PDR, but did not detect any IL- $1 \beta$.

Limb et $a l^{14}$ found much greater IL- $1 \beta$ and IL-6 concentrations in the vitreous of patients with PVR than in those with uncomplicated retinal detachment. Abu el Asrar et $a l^{22}$ found increased IL-1 $\beta$ in the vitreous of $44 \%$ of patients with PDR, but not in their serum or that of controls. Vitreous and serum IL- $1 \beta$ concentrations in PDR were significantly greater than in their controls, an observation that supports the idea of local release of IL-1 $\beta$ from the vitreous or high levels are achieved by a breakdown of the blood retinal barrier. Our PDR patients had significantly greater vitreous and serum IL-1 $\beta$ concentrations than those of Kaufmann et $a l^{23}$ and Abu el Asrar et $a l^{22}$; IL-1 $\beta$ was present in the serum and vitreous of all the PDR patients, the vitreous of $81 \%$ of the controls, and in the serum of $10 \%$ of controls.

Experimental studies show the uveitogenic activity of intravitreally injected TNF- $\alpha$, which also causes increased aqueous humour proteins, corneal neovascularisation and posterior synechia. ${ }^{24}$ Intraocular injection of TNF- $\alpha$ and IL-1 induces factors such as IL-8, IL-6, macrophage colony stimulating factor and monocyte chemotactic protein. ${ }^{11,25}$ Elner et al ${ }^{11}$ detected positive IL-1 $\beta$ and TNF- $\alpha$ in the vitreous of patients with PDR and PVR. Limb et $a l^{14}$ found TNF- $\alpha$ in the vitreous of $22 \%$ of PVR patients, but only in $8 \%$ of uncomplicated retinal detachment patients and controls. However, Abu el Asrar et $a l^{22}$ could detect no TNF- $\alpha$ in the serum, vitreous or aqueous of PDR patients or controls. They suggested that immediate removal of TNF- $\alpha$ from the circulation results in replacement by other cytokines. Kaufmann et $a l^{23}$ observed similar results in patients with PDR, PVR, vitreous haemorrhage, and macular hole. ${ }^{23}$ In our study, vitreous TNF- $\alpha$ concentrations in PDR were greater than in the controls; TNF- $\alpha$ was detected in the serum and vitreous of all the PDR patients, in the vitreous of the controls, and in the serum of most controls; IL- $1 \beta$ and TNF- $\alpha$ were present in all samples from the PDR group. Serum TNF- $\alpha$ concentrations in the PDR patients were significantly greater than in the controls. Vitreous haemorrhage, which is usually present, plus the breakdown of the blood-aqueous barrier by locally produced cytokines, result in the leakage of TNF- $\alpha$ to the systemic circulation. ${ }^{13,15,22}$ The strong correlation we found between vitreous and serum IL- $\beta$ and TNF- $\alpha$ concentrations in the PDR patients can be explained by simultaneous synthesis of IL- $1 \beta$ and TNF- $\alpha$ from the same origin, that is, the RPE and macrophages. In PDR, which is characterised by abnormal cell proliferation and neovascularisation, the increased IL- $1 \beta$ and TNF- $\alpha$ vitreous concentrations are attributed to the role of interleukins in the development of this disease. We suggest that the positive correlation between the vitreous and serum concentrations of these two cytokines requires further investigation.

\section{References}

1 Limb GA, Chignell AH, Green W, LeRoy F, Dumonde DC. Distribution of TNF-alpha and its reactive vascular adhesion molecules in fibrovascular membranes of proliferative diabetic retinopathy. Br J Ophthalmol 1996; 80: 168-173.

2 Limb GA, Soomro H, Janikoun S, Hollifield RD, Shilling J. Evidence for control of tumour necrosis factor-alpha (TNF- $\alpha$ ) activity by TNF receptors in patients with proliferative diabetic retinopathy. Clin Exp Immunol 1999; 115: 409-414.

3 Wiedemann P. Growth factors in retinal diseases: Proliferative vitreoretinopathy, proliferative diabetic retinopathy and retinal degeneration. Surv Ophthalmol 1992; 36: 373-384.

4 Aksunger A, Akbatur H, Or M, Güven D, Okur H, Hasanreisoglu B. The role of interleukin-8 in pathogenesis of advanced proliferative diabetic retinopathy. Ret-vit 1994; 2: 63-66.

5 Ben Ezra D, Hemo I, Maftzir G. In vivo angiogenic activity of interleukins. Arch Ophthalmol 1990; 108: 573-576.

6 Ferrick MR, Thurau SR, Oppenheim MH, Herbort CP, $\mathrm{Ni}$ MingNi, Zachariae COC et al. Ocular inflammation stimulated by intravitreal interleukin-8 and interleukin-1. Invest Ophthalmol Vis Sci 1991; 32: 1534-1539.

7 Akduman L, Or M, Hasanreisoglu B, Gokcora N, Kaplan HJ. Intravitreal interleukin-8 (IL-8) in uveitis. Ret-vit 1994; 2: 279-284.

8 Hoekzema R, Murray PI, Kijlstra A. Cytokines and intraocular inflammation. Curr Eye Res 1990; 9: 207-211.

9 Bhattacherjee P, Henderson B. Inflammatory responses to intraocularly injected interleukin 1. Curr Eye Res 1987; 6: 929-933.

10 Funatsu H, Yamashita H, Shimizu E, Kojima R, Hori S. Relationship between vascular endothelial growth factor and interleukin-6 in diabetic retinopathy. Retina 2001; 21: 469-477.

11 Enler GS, Enler VM, Jaffe GJ, Stuart A, Kunkel S, Strieter RM. Cytokines in proliferative diabetic retinopathy and proliferative vitreoretinopathy. Curr Eye Res 1995; 22: 1045-1053.

12 Reichel E, Duker JS. Diabetic vitrectomy. Curr Opin Opthalmol 1994; 5(3): 50-53. 
13 Davis DM. Proliferative diabetic retinopathy. In: Ryan SJ (ed). Retina. The CV Mosby Company: St Louis, 1994, pp 1319-1360.

14 Limb GA, Little BC, Meager A, Ogilvie JA, Wolstencroft RA, Franks WA et al. Cytokines in proliferative vitreoretinopathy. Eye 1991; 5: 686-693.

15 Arend WP, Daye JM. Cytokines and growth factors. In: Kelley WN, Harris ED (eds). Textbook of Rheumatology. WB Saunders Comp: Philadelphia, 1993, pp 227-246.

16 Ideta R, Yamashita H, Tanaka Y, Kato S, Kitano S, Hori S. Roles of cytokines in diabetic retinopathy. Arch Ophthalmol 1999; 117(5): 700-701.

17 Kojima S, Yamada T, Tamai M. Quantitative analysis of interleukin-6 in vitreous from patients wit proliferative vitreoretinal diseases. Jpn J Ophthalmol 2001; 45: 40-45.

18 Cicik E, Tekin H, Akar S, Ekmekci OB, Donma Koldas L, Ozkan S. Interleukin-8, nitric oxide, and glutathione status in proliferative vitreoretinopathy and proliferative diabetic retinopathy. Ophthal Res 2003; 35: 251-255.

19 Limb GA, Webster H, Soomro S, Janikoun S, Shilling J. Platelet expression of tumour necrosis factor-alpha (TNF- $\alpha$ ), TNF receptors and intercellular adhesion molecule-1 (ICAM-1) in patients with proliferative diabetic retinopathy. Clin Exp Immunol 1999; 118(2): 213-218.
20 Doganay S, Evereklioglu C, Er H, Turkoz Y, Sevinc A, Mehmet $\mathrm{N}$ et al. Comparison of serum NO, TNF- $\alpha$, IL-1 $\beta$, sIL-2R, IL-6 and IL-8 levels with grades of retinopathy in patients with diabetes mellitus. Eye 2002; 16: 163-170.

21 Rosenbaum JT, Samples JR, Hefeneider SH, Hower EL. Ocular inflammatory effects of intravitreal interleukin 1. Arch Ophthalmol 1987; 105: 1117-1120.

22 Abu el Asrar AM, Maimone D, Morse PH, Gregory S, Reder AT. Cytokines in the vitreous of patients with proliferative diabetic retinopathy. Am J Ophthalmol 1992; 114: 731-736

23 Kauffmann DJ, Meurs JC, Mertens AE, Peperkamp E, Master GME. Cytokines in vitreous humor: interleukin-6 elevated in proliferative vitroretinopathy. Invest Ophthalmol 1994; 35: 900-906.

24 Rosenbaum JT, Howes EL, Rubin RM, Samples JR. Ocular inflammatory effects of intravitreally-injected tumor necrosis factor. Am J Pathology 1988; 133: 47-53.

25 Elner VM, Scales W, Elner SG, Danforth J, Kunkel SL, Strieter RM. Interleukin-6 (IL-6) gene expression and secretion by cytokine-stimulated human retinal pigment epithelial cells. Exp Eye Res 1992; 54: 361-368. 